\title{
Contents of Vol.33,1965
}

\section{Review}

Primary Batteries in Japan, KusuhiKo TAKAHASHI and MASAKAZU' MATSUKAWA, No. 2, 65

The Secondary Battery industries in Japan, Hiroshi Tagawa and Toshio Ishik awa, No. 2,72

Fundamental Study of Corrosion and Corrosion Control in Japan, Go OKАмото No. 3, 145

High Temperature Fuel Cells, M. L. KRO NENBERG, No.4, 203

\section{Reports}

Aging Effect of Ferromagnetic Irơ Oxides, YASUO Ima OK A, No.1, 1

An Application of Exoelectron Emission Measurements to the Study of Stressed Surface-Layer of Pure Iron, Go Окамото, Norio Sato and Hiroshi OHaShi, No.1,11

Magnetic Properties and Recording Characteristics of $\mathrm{Fe}_{3} \mathrm{O}_{4}-\gamma \mathrm{Fe}_{2} \mathrm{O}_{3}$ Tapes, $\mathrm{Y}_{\mathrm{ASUO}}$ Imaoka, Minoru Sato and Yasushi Hoshin O, No. 1,19

Studies on the Fused Beryllium ChlorideSodium Chloride System by the Electromotive Force Measuremnt Method, T Tadashi Kuroda and Osamu Matsuио то, No. 1,29
Studies on Thermogalvanic Corrosion. III. Thermogalvanic Corrosion of Copper of $\mathrm{CuSO}_{2}-\mathrm{H}_{2} \mathrm{SO}_{4}$ Solutions, TOMIYA KISHI, Yoshinori Makita, Teisuke Niwa, TAKASHI NAGA and TAKESHI TAKEI, No. 1,35

Effects of Mono and Divalent Cation Chlorides on Molten Sodium Chloride. Seitaro Fukushima, Ryozo OyaMAda and Hisao Hagiwara, No. 1,43

Studies on Ion Exchange Membranes. VI. Electrolysis of Sodium Chloride Solution in Multicompartment Cell with Ion Exchange Membranes and Double Membranes, Toshi Tomizawa, Take o Saito and KENICHI ODA, No. 2, 92

Studies on Ion Exchange Membranes. VII. Electrolysis of Sodium Acetate Solution in Multicompartment Cell with Ion Exchange Membranes and Double Membranes. Toshi Tomizawa and Kenichi ODA, No. 2, 92

Die Anodenvorgänge bei der Elektrolyse von in Kryolith Gelöster Tonerde. I. Paul Drossbach und Tomoyasu HASHINO, No. 2, 101

Die Anodenvorgänge bei der Elektrolyse von in Kryolyth Gelöster Tonerde, II, PAUL Drossbach and Tomoyasu Hashino No. 4, 229

Inhibition of the Corrotion of AluminiumManganes Alloy in Hydrochloric Acid Solution by Butylamines, V.K.V. UNNI and T.L. RAma ChAR. No, 3, 157

The Reaction of Tetraisopropylitranate 
with Salicylic Acid, Shizuo Yamada, Koichiro Kusunoki and WAtaru SAK A I, No. 3, 166

Studies of the Electrolysis of Gypsum, S. NA GESWARA, No. 3, 170

Galvanostatic Determination of Kinetic Parameters of Electrode Reaction with Generation of a Reactant in Situ. SHIN OBU Toshima, Yutaka OKInAKa and HiroSHI OKANIWA, No. 3, 173

On the Surface Diffusion of Adsorbed Atoms in Electrolytic Deposition of Metals, SHIR o HA R U Y A MA , No. 3, 181

Polarization Characteristics of Ion-Exchange Membrane Fuel Cells Yoshinaru Matsuda, Jiro Shiokawa, Hideo $\mathrm{T}_{\mathrm{A}}$ MURA and Toshio Ishino, No. 4, 214

Hydrogen Reduction of Niobimu Pentachloride, Yuzo SAEKI and TADAShi Suzuki, No. 4, 220

Suitability of Commercial Aluminium Alloys as Anode Material in Galvanic Cells, V. BLasubtamanian, P.L. JosePh and B.A. SHENOI, No. 4, 247

\section{Abstracts from the Denki-Kagaku Vol. 33}

Paper Electrophoresis of Photographic Addition Agents. II. VElectrophoresis of Thiourea, Guanidine and Their Derivatives on Paper Wetted with a Butfer Solution Containing Silver Nitrate, SHIN SUZUKI and WATARU TAKAHASHI, No. 1, 53

Galvanostatic Determination of Kinetic Parameters of Electrode Reactions with Generation of a Reactant in Situ SHINOBU Toshima, Yutaka OKINAKA and Hiro SHI OK ANIW A, No. 1, 53
Production of Pure Nickel by the Reduction with Aluminium in Fused Salts, $\mathrm{HA}_{\mathrm{A}}$ Chie Sawamoto, Takeo OKI and Jun TANIKAWA, No. 1,54

Production of Pure Cobalt by the Reduction of Cobalt Chloride $\left(\mathrm{CoCl}_{2}\right)$ with Aluminium in Fused $\left(\mathrm{NaCl}-\mathrm{KCl}-\mathrm{CoCl}_{2}\right)$ Salts, Hachie Sawamoto, Takeo OKI and JUN TANIKA WA, No. 1,54

Studies on the Fuel Cell. II. Studies on a Methanol-Oxygen Fuel Cell, AKIRA Kunugi, Zenichiro TAKEHARA and Shiro Yoshizawa, No. 1,54

Studies on the Fuel Cell. III. Polarization Characteristics of a Hydrazin-Oxygen Fuel Cell, AKira Kunugi, Zenichiro TAKehara and Shiro Yoshizawa, No. 1,55

Anodic Oxidation of Titanium. IV. Preparation and Characteristics of Titanium Solid Electrolytic Slug Capacitors, SHINichi Minami, Wataru Mizushima, Akiyoshi Nomura, Nobuhiro Hamazaki and KOREAKI NAKATA, No. 1, 55

Fuel Cells. XI. Cathodic Polarization of an Oxygen Electrode, KANAME ITO and TAKEHIKO TAKAhASHI, No. 1,56

Fuel Cells. XII. High Temperature LayerBuilt Fuel Cell, KANAME ITO and TAKEHIKO TAKAHASHI, No. 1, 62

Fuel Cell. XIV. High Temperature Fuel Cell with a Pasty Electrolyte, KANAME Iто and TAKEHIKo TAKAhASHI, No. 3, 194

Extraction of Niobium and Tantalum from Some Pegmatitic Ores, RiIchi BABA, KojI IMAGA 56 
The Preparation of High Purity Uranium Metal by the Electrolysis of Fused Uranium Tetrachloride, TADASHI KURODA, No. 1, 56

Production of High Purity Uranium by Fused Salt Electrolysis, KENTARO NAKajima, Masumichi KoIzumi Masahiro Suzuki and TAdashi Kuroda, No. 1, 57

Reduction of Niobium Pentoxide with Magnesium, RIICHI BABA, KOJI IMAGA WA and SHUnJi KiUCHi, No. 1, 57

The Lead Fluoride-Samarium Fluoride System, MASAO SATO and TAIzO UTSUNOMIY A, No. 1,58

Studies on Reactor Construction for Epitaxial Growth of Silicon, SADAO YASUDA and TAKAYUKI NAKAMURA, No. 1,58

Preparation of Silicon Substrate for Epitaxial Growth, SADAO YASUDA and TAK A Y U KI NAK A MURA, No. 1,58

Contributions to the Chemistry of Chlorides of Molybdenum. I. Chlorinations of Molybdenum and its Compounds, YUZO SAEKI, Ryoko Matsuzaki and TAdahisa MATSUSHIMA, No. 1, 59

Contributions to the Chemistry of Chlorides of Molybdenum. II. Thermodynamic Properties of Molybdenum Pentachloride, Yuzo SAEki and Ryoko Matsuzaki, No. 1, 59

Hydrogen Reduction of Niobium Pentachloride, YUZO SAEKI and TADASHI SUZ U K I, No. 1, 60

Contributions to the Chemistry of Chlorides of Molybdenum. III. Chlorination of Molybdenum Trioxide, Yuzo SAEKI, RYOKO MATSUZAKI and TADAhisa Matsushima,
No. 3, 199

Study on a Zirconium-chlorine System, Kotaro Uchimura and Koemon FunaKI, No. 1, 61

Sublimation Pressures and Some Thermodynamic Properties of Zirconium and Hafnium Tetrachlorides, KOEMON FUNAKI and Ko ta ro Uchimura , No. 1, 61

Dechlorination of Zirconium and Hafnium Tetrachlorides with Oxygen and Its Application to the Separation of the I wo Elements, KOEMON FUNAKI and Kotaro UCHIM URA, No. 1, 61

Synthesis and Cation Exchange Properties Phosphoantimonic (V) Acid, TAKUJI ITO and Mitsuo ABe, No. 1, 61

Sorptions of Ammonia and Amines by the Carboxylic Acid Type Ion-Exchange Resin in Heavy Metal Ion Forms, SATSUO KAmata, Kotaro INOUE and Nobuhiko IS HIB A SHI, No. 1,62

Pulse Recording Characteristics of Computer Tape. 1 SHIgEzo TOCHiHARA, Yoshiaki MAKINo and Fumiro SAITo, No. 1, 63

Studies on Corrosion of Metals by Viscoplastic Substances. IV. On the Inhibitive Effect of Phosphate Compounds on the Corrosion of Metals by Viscoplastic Substances, Minoru IZUYAMA, and YASUMASA HAYAKAWA, No. 1, 63

Aging Effects on $\mathrm{Fe}_{3} \mathrm{O}_{4}-\gamma \mathrm{Fe}_{2} \mathrm{O}_{3}$ Maynetic Tapes at Room Temperature, YASUO ImAO K A, No. 1, 64

Vicissitude of the Electrodeposition Stress and the Post-electrodeposition single Electrode Potential of Lead Dioxide, YAS UIC H I SHIB A S A KI, No. 2, 133 
Studies on the Electrolytic Preparation of Sugars. XIX. The Refining of a Wood Saccharification Solution by AlternateCurrent Electrolysis Using Soluble Electrodes, Jun Mizuguchi, Shuichi Suzuki and Yoshio Uetani, No. 2, 133

High Temperature Aging Effect of $\mathrm{Fe}_{3} \mathrm{O}_{4}^{-}$ $\gamma \mathrm{Fe}_{2} \mathrm{O}_{3}$ Magnetic Tapes, Yasuo IMAOKA, No. 2, 134

On Silver Dendrites Electrocrystallised from a Sulfamate Bath, MINORU KIKUCHI and RYUICHI YAMAZAKI, No. 2, 134

Oxidation of $\mathrm{Fe}_{3} \mathrm{O}_{4}$ Magnetic Tapes, YASUO IM A O K A, No. 2, 135

The Thermal Decomposition of Sodium lodate, KENICH WATANABE and SHOICHI Shimizu, No. 2, 135

Studies on Rare Earth Elements. XIV. Separation of Cerium Group Rare Earth by the Ion Exchange Method Using $0.1 \%$ Citrate Solution as Eluant, JiRo SHioKAwA, Tomoo YonebayASHi and ToSHIO ISHINO, No. 2, 136

Studies on Rare Earth Elements. XV. Decomposition Voltage of Fused Lanthanum Chloride, Jiro Shiokawa, ToshiYuki Fujiwara, Tetsuo Watanabe, Nobuo Nishie and Toshio Ishino, No. 2, 136

Studies on Air Electrodes. 1. Baked Carbon and Plastic Bonded Carbon Electrode as Air Electrodes, SABURo MAKINO, No. 2, 137

Studies on the Dissolution of Lead from an Anode Composed of Lead Sulfide Concerntrate and Graphite Powder, $\mathrm{H}_{\mathrm{ACHIE}}$ SAwamoto, TAKEO OKI and SHIgEKI ONO, No. 2, 138

Optimum Conditions for Preparing Chlo- rine Dioxide by Conventional Methods, KENICHI WATANABE and SHOICHI SHIMIZ U, No. 2, 138

Studies on the Activation of Manganese Dioxide for Dry Batteries by Chemical Treatment. I. MAKOTO ANAYAMA, SAKAE KASORI and KUSUHIKO TAKAHASHI, No. 2, 138

Studies on Magnetic Recording Films Evaporated. II. Evaporated Iron Magnetic Recording Films and Their Properties, Yoshichika Makino, Yasushi Hoshino and MINORU SATO, No. 2, 139

Effects of Mono-and Divalent Cation Chlorides on Molten Sodium Chloride, SE IT A R O FukUshima , RYOZO OYAMADA and His a O Ha Giw a R a, No. 2, 139

Studies of a Fused Beryllium ChlorideSodium Chloride System by Electromotive Force Measurement, TADASHI KURODA and Osamu Matsumoto, No. 2, 140

Studies on an Electrochemical Inte grator. Ion Transfer Between Pair of Plate Electrodes Placed in Parallel and Integrating Function, Komei ASAI, TAKETSUgU Hirai and Natsuki Kawashima, No. 2, 140

Studies on an Electrochemical Integrator. II. Electrochemical Integrator and Its Performance for Direct Current Inputs, KoMei Asai, Taketsugu Hirai and MaSATARO FUKUDA, No. 4, 2652

Studies on an Electrochemical Integrator. ill. Electrochemical Integrator and Its Performance for Low Frequency Sine Wave Imputs, Komei ASAI, TAKetsugu HIRAI and MASATARo FUKUdA No. 4, 262

Studies on Corrosion of Steel in Water at Elevated Temperature and Pressure. I. Corrosion of Mild Steel in High Temper- 
ature Sodium Hydroxide Solutions, OSAMU Asai and Natsuki Kawashima, No. 2, 141

Studies on Electrorefining of Aluminium in $\mathrm{NaF}-\mathrm{Et}_{3} \mathrm{Al}-\mathrm{C}_{6} \mathrm{H}_{5} \mathrm{CH}_{3}$ System Electrolytic Solution, HACHIE SAwAmoto, TAKEO OKI and Noboru Hishida, No. 2, 141

Some Dielectric Properties of Deposited Silicon Monoxide Films, AKIRA MARUyAMA and SHINICHI YANO, No. 3, 190

The Conductivity of Solid Electrolytes. IV. On $\mathrm{Ag}_{3} \mathrm{SI}-\mathrm{AgI}$ and $\mathrm{Ag}_{3} \mathrm{SI}-\mathrm{Ag}_{2} \mathrm{~S}$ Solid Solutions, TAKEHIKO TAKAHASHI and OSAmu Yamamoto, No. 3, 190

Ferrite Magnetic Recording Head Employing Glass Spacer, Fu K U Z O IT o, MAMORU NAMIKAWA, YUKIO ANDO and SOKICHI OT A, No. 3, 190

Study on Dielectric Constants. I. The Relationship Between the Dielectric Constants of Ionic Crystals and Their Radii, Yuichi Kamura and Eiko Ogura, No. 3, 191

Electrolytic Preparation of Iso-Propylamine, KeIJIR O Odo, EIICHI ICHIKA WA and Kiy OTA K A Morita, No. 3, 191

Solid Electrolyte Cell. II. The Polarization Behaviour of Solid Electrolyte Cell, TAKehiko TAKahashi and Osamu YAM А М то, No. 3, 191

Electrochemistry of Platinum Group Metals. IV. On Platinum-Plated Electrode, HiroNobu Yamamoto, YoshikaZU KoKUBU. Kayoko NeZu, TAKAShi NAgai and TAKESHI TAKEI, No. 3, 192

Electrochemistry of Platinum Group Metals. V. Fundamental Studies on the Platinumplated Magnetite Electrode, HiRONOBU Yamamoto, YoshikaZU KokUBU, KA-
Y OKO NEZU, TAKASHI NAGAI and TAKESHI TAKEI, No. 3, 192

Electrochemistry of Platinum Group Metals. VI. Cathodic Reduction of Nagnetite Electrode, Hironobu Yamamoto, YoshiKaZU KOKUBU, KaYoko NEZU, TAKaShI NAgAi and TAKeShi TAKei, No. 3, 193

Electrochemistry of Platinum Group Metals. VII. Cathodic Reduction of $\mathrm{PtCl}_{6}^{2-}$, HIRONOBU YAMAMOTO, YoshiKaZU KOKUBU, TAKASHI NAGAI, and TAKESHI TAKEI No. 4, 261

Growth Faults in Silver Crystallites Produced by Silver Mirror Reaction, TosHImichi Takiguchi and EIIChi ASAda, No. 3, 193

Fuel Cell. XIII. Pd-Hydrocarbon Gas Electrodes at High Temperature, TAKEHiko TAKAhASHI, KANAmE ITO and SEIICHi NAK AmuRA, No. 3, 194

A Study of Systematic Analysis of Acid Radicals by Means of Electro-chromatography. XV. On the Chromatogram Produced by Movable Electrode Method, SHIG EICHI ACHIW A, No. 3, 195

Corrosion of Iron in High Temperature and Pressure Water. I. The Corrosion Rate and the Structure of Product Films, TAKAShi MUKaibo and Shigeniko MasuK A W A, No. 3, 195

Electrodeposition of Aluminum from Fused Salt Bath. I. Measurement of Overvoltage, TAdaO Hayashi, Yoshiniko KUwa, Makoto Yoshida and Nobuo Kikuмо то, No. 3, 195

Studies on Ion Exchange Membr anes. XXIV. Permselectivity of the Amphoteric Ion EXchange Membranes. 2, Reilchi Yamane, 
Ryuzi Izuo and Yukio Mizutani, No. 3, 196

The $\psi$-Effect on the Polarographic Reduction of Chromate lons, SHinoBu Toshima, Isamu Uchida and Minoru Hasegawa, No. 3, 197

The Degree of Inhalation of Air into the Electrolytic Cell Having and Exhaust Pipe for Hydrogen, HiROSHI IMAGAWA and YOShIE TANAKA, No. 3, 197

The Anodic Oxidation of Esters. III., Toshiniko Okubo and Shigeru TsuTS UMI, No. 3, 197

Aging Effect and Thermal Demagnetization of the Magnetic Iron Oxide Tapes, YASUO IM A O K A, No. 3, 198

The Anodic Oxidation of Lower Alcohols in Alkaline Electrolyte, SACHIO TAKAHASHI and Yoshizo Miya ke, No. 3, 198

The Niobium Tritaoctachloride-Alkali Metal Chloride System, Yuzo SAEKI, TADAShi Suzuki and Shinsuke Yamaki, No. 3 , 199

Studies on High Temperature Fuel Cell. II. The Polarization Characteristics of Anode, Koichi Shiota, Hiroshi Noda, Jiro Shiokawa, Hideo Tamura and Toshio IsHino, No. 4, 256

Studies on High Temperature Fuel Cell. III. The Polarization Characteristics of Cathode, Koichi Shiota, Hiroshi Noda, Jiro Shiokawa, Hideo Tamura and Toshio Ishino, No. 4, 256

Preparation of Pure Vanadium Metal from $\mathrm{V}_{2} \mathrm{O}_{3}$, SAKaE TAKeuchi, OSAmu WataNABE and Hideya Watanabe, No. 4, 256
Studies of Lead Alloy Anodes for Cathodic Protection. XII. Anodic Behavior of Silver in Sodium Sulfate Solutions, Eirchi SA to, No. 4, 257

Stress in the Oxide Films of Zirconium and Zircaloy-2 during Anodic Oxidation, Sue O Nomura, Cho AKutsu and Ichiro SARUYAMA, No. 4, 258

The Electrical Double Layer in Low Melts. I. Ammonium Nitrate-Water and Ammonium Nitrate-Lithium Nitrate Systems, TAKUYA ARA and KEIICHi EDA, No. 4, 258

Preparation Procedures of Positive Plates for Sintered Plate Alkaline Batteries Using Thermal Decomposition in Steam, TS U т o M U IW A K I and MASATARO FUKUDA, No. 4, 258

Electrical Conductivity of Solid Electrolytes. $V$. Electrical Conductivity in a $\mathrm{Ag}_{2} \mathrm{~S}-\mathrm{Ag}_{2} \mathrm{Hgl}$, System, TAKEнIKо TAKAHAShi and Osamu Yamamoto, No. 4, 259

Studies of a Methanol Fuel Cell. I. Studies of the Anodic Character of Nickel Electrodes in a Methanol Fuel Cell, Hideo Tamura, Yoichi Imamura, Shinichiro Iw ANAGA and Toshio Ishino, No. 4, 259

Red Emission of Electroluminescent ( $\mathrm{Zn}$, Cd)S-type Phosphors, TAKASHI HARIU, KA ZuO MiYashita and MASAnOBU WAd, No. 4,260

Interfacial-Electrochemical Studies on Non-aqueous Dispersions of Pigments. II. An Idea on Electrokinetic Phenomena in Colloid Systems, NoBuAtsu WATANABE, ISAO TARI and SHIRo YoshizAWA, No. 4,260

Pulse Recording Characteristics of Computer Type. II. Shigezo Tochinara, YOSHIAKI MAKINO and MAMORU NAMIK AWA No. 4, 261 
Effects of Mono- and Di-valent Salts on Molten $\mathrm{KCl}$ and a Mizture of $\mathrm{NaCl}-\mathrm{KCl}$ $(1: 1)$, Hisao Hagiwara, Ryozo Oyamada and Seit aro FukUShima, No. 4 ,

Oxidation of Magnetite Powder by Fused Salts, YASUо IмAOK A, No. 4, 263

Digital Magnetic Recording Tape Made with Co-doped $\gamma$ - $\mathrm{Fe}_{2} \mathrm{O}_{3}, \mathrm{SHIGEzO}$ ToCHIHARA, YOSHIAKI MAKINO and FUMIRO SAITO, No. 4, 263

The Frictional Resistance of Magnetic Recording Tape, Shigezo Tochinara, Yoshiaki Makino and Munemitsu Chitosehara, No. 4,264

Studies on the Cell Using Ion Exchange Membranes. I. A Concentration Cell Using
Ion Exchange Membranes, TAKEO MATSUNO and Hideo ONOUE, No. 4, 264

Studies of Carbon Electrodes for LowTemperature Air Hydrogen Fuel Cells, MASAmi KATSUda and Tokuzo ToNOMURA, No. 4, 264

On the Production of Persulfate by Electrolys is of Sodium Sulfate Solution. IV. Effect of Mercury Contamination on the Production of Persulfate and Hydrogen Peroxide, Masamichi Yamashita, Masao Kubokawa, Fumio Hine and Shiro YoshiZ Aw A, No. 4, 265

Studies of Colour Centers Produced in Cahalophosphate Matrix under Radiation by Various Rays, SHIgerU KAMIYA and Haruo Shib a Ta, No. 4, 265

\section{Author Index to Vol.33,1965}

A

Abe, Mitsuo

Achiwa, Shigeichi

Akutsu, Cho

Anayama, Makoto

Ando, Yukio

Ara, Takuya

Asada, Eiichi

Asai, Komei

Asai, Osamu

B

Baba, Riichi

Blasubtamanian, V.

C

Chitosehara, Munemitsu

D

Drossbach, Paul

E

Eda, Keiichi
Page Fujiwara, Toshiyuki 136

61 Fukuda, Masataro 258,262

195 Fukushima, Seitaro 43,139,262

258

138

190

258

193

140,262

141

56,57

247

264

Funaki, Koemon

61

$\mathrm{H}$

Hagiwara, Hisao $\quad 43,139,262$

Hamazaki, Nobuhiro $\quad 55$

Hariu, Takashi

Haruyama, Shiro

Hasegawa, Minoru

Hashino, Tomoyasu

Hayakawa, Yasumasa

Hayashi, Tadao

Hine, Humio

Hirai, Taketsugu

Hishida, Noboru

Hoshino, Yasushi

101,229

I

Ichikawa, Eiichi

258

140,262

141

19,139
Imagawa, Hiroshi

Imagawa, Koji

Imamura Yoichi
Imaoka, Yasuo $\quad 1,19,64,134$

$135,198,263$

Inoue, Kotaro 62

Ishibashi, Nobuhiko $\quad 62$

Ishikawa, Toshio $\quad 72$

Ishino, Toshio $\quad 136,214$

256,259

Ito, Fukuzo $\quad 190$

Ito, Kaname $\quad 56,62,194$

Ito, Takuji 61

Iwaki, Tsutomu 258

Iwanaga, Shinichiro $\quad 259$

Izuo, Ryuzo 196

Izuyama, Minoru 63

J

Joseph, P.L.

247

K

Kamata, Satsuo $\quad 62$

191 Kamiya, Shigeru 265

197 Kamura, Yuichi 191

56,57 Kasori, Sakae 138

259 Katsuda, Masami 264 